\title{
PAWEt LATUSEK
}

Poznań, na 24 czerwca 2015 roku

Przewielebny Księże Arcybiskupie Metropolito,

Czcigodny Księże Profesorze,

Kochany Marku!

Już ponad miesiąc temu Pan profesor Krzysztof Stachewicz przekazał mi zaproszenie na uroczyste spotkanie z Tobą, organizowane z okazji wręczenia Ci Księgi Pamiątkowej: Deum et animam scire. Cieszyłem się na to spotkanie i wierzyłem, że wezmę w nim udział. Niestety, w tym czasie (22-24.06) Sekretariat Konferencji Wyższych Przełożonych zorganizował w Kielcach szkolenie dla sekretarzy prowincjalnych, prowadzone przez przedstawicieli Biura Prawnego Episkopatu, Ministerstwa Administracji i Cyfryzacji, Generalnego Inspektoratu Ochrony Danych Osobowych oraz Zespołu ks. Adama Żaka SJ. Ze względu na moje obowiązki muszę być na tym spotkaniu.

Czas biegnie niczym tkackie czótenko... Jubilacie drogi, minęły długie lata, a wydaje się, że to tak niedawno spotkaliśmy się w auli Papieskiego Uniwersytetu Gregoriańskiego (poznałem Cię przez leżący przed Tobą słownik włosko-polski). Zbliżył nas Rzym, uniwersytet, wykłady, nasz profesor-promotor - o. Simon Decloux SJ, a nawet „szlifierz” językowy naszych dysertacji - pan profesor Vincenzo del Pinto. Dzisiaj Bogu dziękuję za tamto rzymskie spotkanie, które zrodziło wzajemną życzliwość i przyjaźń, a za wierność tej wzajemnej relacji dziękuję również Tobie.

$\mathrm{Na}$ temat Twojej drogi naukowej i jakże licznych owoców Twojego naukowego zaangażowania padnie dziś wiele słusznych słów. Pozwól, że w tym krótkim adresie przywołam ciagle mi drogi obraz, który zachowuję w pamięci od czasu mojego dwuletniego stażu misyjnego w Kamerunie: obraz ogniska. W tamtym czasie, na początku lat siedemdziesiątych, ognisko było czymś niesamowicie ważnym w każdej zagrodzie: emanowało światło, przy nim można było się ogrzać w chłodną noc, ale przede wszystkim nad nim kobiety gotowały posiłek. Ponieważ w wielu zagrodach nie było zapałek, więc zazwyczaj o zmierzchu mogłem widzieć kobiety, które w jakiejś glinianej skorupie niosły rozżarzone węgle podebrane $\mathrm{z}$ ogniska sąsiadki, aby nimi rozpalić ognisko we własnej zagrodzie.

Carissime, patrząc na lata naszej znajomości, dostrzegam, że jesteś panem dwóch ognisk: filozoficznego i kapłańskiego. Na pierwsze ognisko składa się twoja praca naukowo-dydaktyczna: wykłady, seminaria, publikacje, kongresy, sympozja... Sam Bóg wie, jak liczni są ci, którzy zabierając rozżarzone węgle 
z tego ogniska, rozpalili własne. Drugie ognisko to Twoja posługa kapłańska i biskupia. Wiem, jak bardzo dbasz o nie. I słusznie, bo o ile w pierwszym musi starczyć węgli dla zainteresowanych mądrością, o tyle w drugim musi ich wystarczyć dla wszystkich. Scire Christum - oto jego paliwo. Augustyńskie Deum et animam scire pięknie łączy te dwa ogniska, a jest to możliwe dlatego, że łączy je Twoje życie. Tobie, Marku życzę, a Boga w modlitwie proszę, aby te dwa ogniska jeszcze długo się paliły $\mathrm{i}$ aby węgle $\mathrm{z}$ nich podbierane były zarzewiem wielu nowych ognisk, tak w wymiarze przyrodzonym, jak i przede wszystkim w wymiarze nadprzyrodzonym. 